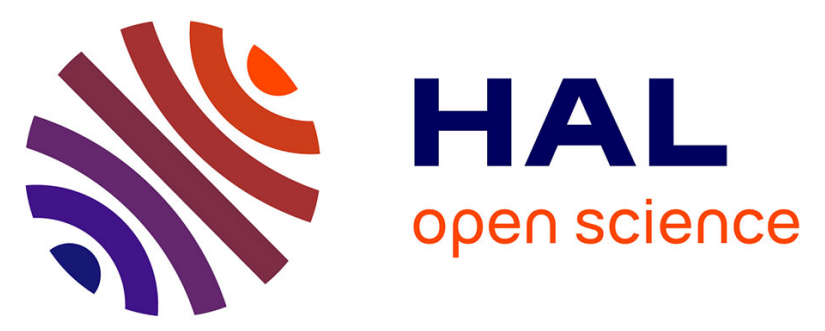

\title{
Individual Differences as a Key Factor to Uncover the Neural Underpinnings of Hedonic and Social Functions of Human Olfaction: Current Findings from PET and fMRI Studies and Future Considerations
}

Marylou Mantel, Camille Ferdenzi, Jean-Michel Roy, Moustafa Bensafi

\section{To cite this version:}

Marylou Mantel, Camille Ferdenzi, Jean-Michel Roy, Moustafa Bensafi. Individual Differences as a Key Factor to Uncover the Neural Underpinnings of Hedonic and Social Functions of Human Olfaction: Current Findings from PET and fMRI Studies and Future Considerations. Brain Topography: a Journal of Cerebral Function and Dynamics, 2019, 32 (6), pp.977-986. 10.1007/s10548-019-00733-9 . hal-03098250v2

\author{
HAL Id: hal-03098250 \\ https://hal.science/hal-03098250v2
}

Submitted on 5 Jan 2021

HAL is a multi-disciplinary open access archive for the deposit and dissemination of scientific research documents, whether they are published or not. The documents may come from teaching and research institutions in France or abroad, or from public or private research centers.
L'archive ouverte pluridisciplinaire HAL, est destinée au dépôt et à la diffusion de documents scientifiques de niveau recherche, publiés ou non, émanant des établissements d'enseignement et de recherche français ou étrangers, des laboratoires publics ou privés. 


\title{
Individual Differences as a Key Factor to Uncover the Neural Underpinnings of Hedonic and Social Functions of Human Olfaction: Current Findings from PET and fMRI Studies and Future Considerations
}

\author{
Marylou Mantel ${ }^{123}$, Camille Ferdenzi ${ }^{4}$, Jean-Michel Roy ${ }^{5}$, Moustafa Bensafi ${ }^{67}$
}

- PMID: 31564029

- DOI: $10.1007 / \mathrm{s} 10548-019-00733-9$

\section{Abstract}

The hedonic and social dimensions of olfactory perception are characterized by a great diversity across people. Whereas the cerebral processing underlying these aspects of odor perception have been widely explored in the last decades, very few brain imaging studies considered individual differences. This lack of consideration weakens the current models in the field, where the paradigm of universality is the norm. The present review is aimed at examining this issue. Through a synthetic summary, we will first present past studies suggesting that (1) hedonics are represented consistently throughout the olfactory system from primary to secondary areas, with a progressive cognitive modulation and integration with other senses, (2) social dimension of odors may be represented in a distinct pathway involving social and attentional networks. In a second, and more critical part, we will highlight the importance of individual differences for the cerebral study of human olfaction.

Keywords: Hedonics; Olfaction; PET; Perception; Representation; Social; Variability; fMRI. 